\title{
Piotr Pisarewicz
}

Uniwersytet Gdański

e-mail: piotr.pisarewicz@wp.pl

\section{Patrycja Kowalczyk-Rólczyńska}

Uniwersytet Ekonomiczny we Wrocławiu e-mail: patrycja.kowalczyk@ue.wroc.pl

\section{Wojciech Kamieński}

eskpert w biurze Rzecznika Finansowego

e-mail: wojciech.kamienski@gmail.com

\section{FORMALNOPRAWNY I INSTYTUCJONALNY WYMIAR SYSTEMU OCHRONY KLIENTÓW W ZAKRESIE UBEZPIECZEŃ NA ŻYCIE, GDY RYZYKO LOKATY (INWESTYCYJNE) PONOSI UBEZPIECZAJĄCY}

\section{THE FORMAL, LEGAL AND INSTITUTIONAL ASPECT OF CUSTOMER PROTECTION SYSTEM IN LIFE INSURANCE WHERE THE INVESTMENT RISK IS BORNE BY THE POLICYHOLDERS}

DOI: 10.15611/nof.2017.3.07

JEL Classification: G22, G28, K220

\begin{abstract}
Streszczenie: Celem opracowania jest analiza wybranych zagadnień dotyczących formalnoprawnego i instytucjonalnego wymiaru systemu ochrony klientów w zakresie ubezpieczeń na życie, gdy ryzyko lokaty (inwestycyjne) ponosi ubezpieczający. Podjętym problemem badawczym jest ocena praktycznej skuteczności systemu ochrony klientów w badanym obszarze rynku finansowego. Autorzy opracowania ocenili formalnoprawny oraz instytucjonalny wymiar ochrony klientów w naszym kraju jako prawidłowy i nie budzący większych zastrzeżeń. Podkreślili równocześnie, iż w sferze operacyjnej i praktycznej organy powołane przez państwo mogły podejmować w przeszłości więcej działań skuteczniej chroniących odbiorców usług finansowych. Zwrócono także uwagę na konieczność podejmowania dalszych kroków mających na celu poprawę pozycji klientów w przyszłości, czemu służyć powinny zarówno zapisy prawa, jak i procedury oraz działania powołanych do tego instytucji.
\end{abstract}

Słowa kluczowe: ochrona klienta, zakład ubezpieczeń, produkt ubezpieczeniowy, ubezpieczenia na życie, organ nadzoru, regulacje prawne rynku ubezpieczeniowego. 


\begin{abstract}
Summary: The aim of the paper is to analyze selected issues concerning the formal, legal and institutional aspect of the life insurance system of clients when the investment risk is borne by the policyholders. The research problem is the critical opinion and conclusion about the practical effectiveness of the customer protection system in Poland. The authors of the paper evaluated the formal, legal and institutional aspects of customer protection system in our country as correct and not objectionable.They emphasized at the same time that, in the sphere of operation, the State authorities have been able to undertake more effective actions in the past to better protect the consumers of financial services. Attention has also been paid to the need to take further steps aimed at improving the position of customers in the future, both for the purposes of law and for the procedures and activities of the State institutions.
\end{abstract}

Keywords: client protection, insurance company, insurance product, life insurance, supervisory authority, insurance market regulation.

\title{
1. Wstęp
}

Dynamiczny rozwój rynków finansowych oraz oferowanych produktów skutkuje koniecznością zapewnienia jak najwyższego poziomu bezpieczeństwa systemowego oraz ochrony klientów. Organami do tego powołanymi są zarówno instytucje państwowe (np. Komisja Nadzoru Finansowego, Urząd Ochrony Konkurencji i Konsumentów, Rzecznik Finansowy), wszelkiego rodzaju organizacje branżowe i sektorowe (np. Polska Izba Ubezpieczeń, Związek Banków Polskich), jak i organizacje powołane przez samych klientów (organizacje konsumenckie). Ta dość spora grupa podmiotów powinna być wystarczająca, aby zapewnić bezpieczeństwo nie tylko klientom korzystającym z usług finansowych, lecz także podmiotom, które te usługi oferują.

Wieloletnia już praktyka rynkowa wskazuje, że choć pełniony jest nadzór nad rynkiem finansowym, to jednak rynek usług finansowych nie jest niezawodny. W literaturze przedmiotu (m.in. [Marcinkowska 2011]) wskazuje się kilka podstawowych przyczyn zawodności tego rynku: niedoskonałą informację, upadłość instytucji finansowych (banków, zakładów ubezpieczeń), kryzysy systemowe oraz zniekształcenie konkurencji. Istotne znaczenie dla prawidłowości funkcjonowania rynku finansowego, a tym samym sektora ubezpieczeniowego, ma pierwsza z wymienionych przyczyn - niedoskonała informacja. A. Borkowski [2012] wskazuje na istotne wątpliwości w kwestii przekazu stosownych informacji osobom poszukującym ochrony ubezpieczeniowej przez pośredników ubezpieczeniowych (agentów, multiagentów, brokerów ubezpieczeniowych oraz podmiotów działających na podstawie art. 3 Ustawy o pośrednictwie ubezpieczeniowym [Ustawa z 22 maja 2003] $]^{1}$ ). Jest to sytuacja bardzo niepokojąca, ponieważ jednym z ważniejszych obszarów

${ }^{1}$ Artykuł 3 ust. 2 Ustawy o pośrednictwie ubezpieczeniowym umożliwia, aby określone produkty ubezpieczeniowe były dystrybuowane przez podmioty nieposiadające statusu pośrednika ubezpieczeniowego (więcej w: [Borkowski 2012]). 
działalności pośredników ubezpieczeniowych powinno być łagodzenie skutków związanych z asymetrią informacji, a tym samym profesjonalne doradzanie klientom [Przybytniowski 2014]. Nadmienić należy, że właśnie niewłaściwa sprzedaż (a tym samym nieudzielanie przez pośredników ubezpieczeniowych wyczerpujących informacji na temat charakteru prawnego produktu) w przypadku ubezpieczeń na życie gdy ryzyko lokaty (inwestycyjne) ponosi ubezpieczający², stała się przyczyną wielu problemów w zakresie tej gamy produktów [Mrozowska-Bartkiewicz 2013; Wrzesiński 2015] i jednocześnie istotnie naruszyła zaufanie klientów do całego rynku finansowego. Niejednokrotnie problem ten zauważany był przy sprzedaży ubezpieczeń na życie z UFK poprzez bankowy kanał dystrybucyjny (bancassurance). Wielokrotnie banki nakłaniały klientów do przystąpienia (w charakterze czy to ubezpieczającego, czy to ubezpieczonego) do ubezpieczeń na życie z UFK, których zakres był niedostosowany do ich indywidualnych potrzeb [Sury 2014].

Zakres potrzebnej ochrony zależy także od świadomości ubezpieczeniowej klientów, czyli od ich wiedzy i umiejętności, pozwalających na racjonalne korzystanie z tego typu usług (więcej w: [Szumlicz 2006]). Przegląd różnych definicji świadomości ubezpieczeniowej można znaleźć w pracach: [Wieteska 2010; Grzebieniak 2008; Iwko, Iwko 2015; Walczak, Żołądkiewicz 2011]. Im niższy jest poziom świadomości ubezpieczeniowej klientów, tym wyższa powinna być ochrona tych klientów. Dodatkowo rola pośrednictwa ubezpieczeniowego w tej grupie klientów powinna być zdecydowanie większa. Niestety - jak pokazują wyniki kontroli ochrony interesów klientów (m.in. zakładów ubezpieczeń) przeprowadzonej przez Najwyższą Izbę Kontroli zarówno w 2010 r., jak i w 2013 r. (więcej w: NIK 2011, 2014]) ochrona interesów klientów zakładów ubezpieczeń nie była dostatecznie skuteczna. Nastąpiło to pomimo tego, iż Rzecznik Ubezpieczonych, Urząd Komisji Nadzoru Finansowego, Urząd Ochrony Konkurencji i Konsumentów oraz rzecznicy konsumentów, w ramach posiadanych kompetencji i obowiązków, rzetelnie wspierali konsumentów w rozwiązywaniu sporów z ubezpieczycielami oraz prowadzili działalność edukacyjno-informacyjną.

Biorąc pod uwagę powyższe fakty, należy podkreślić rolę i konieczność sprawowania ochrony klientów w zakresie usług ubezpieczeniowych przez różne organy państwowe. $Z$ tego względu celem niniejszego opracowania jest analiza wybranych zagadnień dotyczących formalnoprawnego i instytucjonalnego wymiaru systemu ochrony klientów w zakresie ubezpieczeń na życie, gdy ryzyko lokaty (inwestycyjne) ponosi ubezpieczający. Podjętym problem badawczym jest przeprowadzona na podstawie tej analizy ocena praktycznej skuteczności systemu ochrony klientów w badanym obszarze rynku finansowego. Produkty ubezpieczeniowe jako takie, a w szczególności produkty obejmujące grupę 3 działu I załącznika do Ustawy

\footnotetext{
${ }^{2} \mathrm{~W}$ niniejszym artykule wymiennie będą stosowane nazwy: ubezpieczenia na życie, gdy ryzyko lokaty (inwestycyjne) ponosi ubezpieczający, oraz ubezpieczenia na życie z ubezpieczeniowym funduszem kapitałowym (UFK).
} 
o działalności ubezpieczeniowej i reasekuracyjnej [Ustawa z 11 września 2015], w ostatnich dekadach powodowały bardzo dużo kontrowersji związanych zarówno $\mathrm{z}$ ich konstrukcją oraz stroną formalnoprawną, jak i ze sposobem dystrybucji oraz wynagradzaniem pośredników. $Z$ tego względu uwaga autorów skupiona została właśnie na tej klasie produktów. Ze względu na ograniczone ramy redakcyjne, w niniejszym opracowaniu skupiono się jedynie na wybranych zagadnieniach związanych z tym tematem. W początkowej części przedstawiono syntetyczne statystyki rynkowe obejmujące decyzje i kary UOKiK dla zakładów ubezpieczeń oraz skargi i wnioski kierowane do Rzecznika Finansowego, ukazujące ramowo skalę problemu. W kolejnej części uwaga skupiona została na najważniejszych kwestiach formalnoprawnych obejmujących regulacje dotyczące nadzoru nad rynkiem finansowym oraz samego sektora ubezpieczeniowego, które stanowią ramy dla pozostałych uregulowań sektorowych i konsumenckich. Instytucjonalny wymiar ochrony klientów związany z działalnością głównych organów do tego powołanych opisany został w końcowej części opracowania.

\section{Ochrona klientów w świetle statystyk rynkowych}

Urząd Ochrony Konkurencji i Konsumentów pełni niezwykle ważną funkcję w aspekcie kontroli poprawności działań zakładów ubezpieczeń, banków i innych instytucji finansowych ${ }^{3}$ oferujących ubezpieczenia na życie z UFK lub pośredniczących w sprzedaży tych produktów, w stosunku do klientów, którzy z tych produktów korzystają. Od 2014 r. prezes tego urzędu wydał 22 decyzje dotyczące ubezpieczeń na życie z UFK w toku postępowań w sprawie naruszenia zbiorowych interesów konsumentów ${ }^{4}$. W większości tych decyzji można znaleźć istotne zalecenia (konieczne do wdrożenia w określonym przez UOKiK czasie) i nakazy zaniechania wskazanych $\mathrm{w}$ decyzjach praktyk stosowanych przez te instytucje w ramach produktów ubezpieczeń na życie z UFK. W przypadku niektórych decyzji prezes UOKiK nałożył stosowne kary pieniężne płatne do budżetu państwa. Wysokość tych kar wraz z informacją, która instytucja została zobowiązana do jej zapłaty, jak i powód nałożenia kar zaprezentowano w tab. 1.

Nałożone kary pieniężne oraz wydane decyzje stały się ważnym sygnałem nie tylko dla instytucji finansowych oferujących ubezpieczenia na życie z UKF oraz dla instytucji pośredniczących w sprzedaży tych produktów, ale również dla klientów,

\footnotetext{
${ }^{3}$ W grupie instytucji finansowych, w stosunku do których zostały wydane decyzje Prezesa UOKiK znajdują się: Aegon TU na Życie S.A., Aviva TU na Życie S.A., AXA Życie TU S.A., Compensa TU na Życie S.A. VIG, Generali Życie TU S.A., MetLife TU na Życie i Reasekuracji S.A., Nationale-Nederlanden TU na Życie S.A., Open Life TU Życie S.A., PKO Życie TU S.A., PZU Życie S.A., Pramerica Życie TUiR S.A., Skandia Życie TU S.A., STU na Życie Ergo Hestia S.A., TU Allianz Życie Polska S.A., TU na Życie Europa S.A., TU na Życie WARTA S.A., UNIQA TU na Życie S.A., TAX CARE S.A., Raiffeisen Bank Polska S.A., Idea Bank S.A., Open Finance S.A.

${ }^{4}$ Wszystkie te decyzje dostępne są na: https://finanse.uokik.gov.pl/ufk/decyzje-uokik (4.07.2017).
} 
Tabela 1. Wysokość kar nałożonych przez prezesa UOKiK za praktyki naruszające zbiorowe interesy konsumentów dotyczące ubezpieczeń z ubezpieczeniowym funduszem kapitałowym

\begin{tabular}{|c|c|c|c|}
\hline $\begin{array}{l}\text { Nazwa zakładu } \\
\text { ubezpieczeń }\end{array}$ & Nr decyzji & $\begin{array}{l}\text { Wysokość kary } \\
\text { pieniężnej (zł) }\end{array}$ & Główna przyczyna nałożenia kary \\
\hline $\begin{array}{l}\text { Aegon TU na } \\
\text { Życie S.A. }\end{array}$ & RBG-30/2014 & 23446206 & $\begin{array}{l}\text { brak zaprzestania pobierania opłat } \\
\text { zakazanych przez Sąd Ochrony Konkurencji } \\
\text { i Konsumentów, zmiana sposobu ich } \\
\text { obliczania, skutkująca niekorzystną dla } \\
\text { klientów modyfikacją umowy ubezpieczenia }\end{array}$ \\
\hline $\begin{array}{l}\text { Open Finance } \\
\text { S.A. }\end{array}$ & RKT-29/2014 & 1673546 & \multirow{2}{*}{$\begin{array}{l}\text { wprowadzanie konsumentów w błąd } \\
\text { w zakresie ryzyka związanego z inwestowaniem } \\
\text { środków pieniężnych w ramach ubezpieczeń } \\
\text { na życie z UKF, poprzez wyeksponowanie } \\
\text { korzyści związanych z inwestycją kosztem } \\
\text { informacji dotyczących okoliczności, } \\
\text { w których inwestycja może nie przynieść zysku } \\
\text { lub wygenerować straty, a także kosztów } \\
\text { związanych z rozwiązaniem umowy w trakcie } \\
\text { jej trwania }\end{array}$} \\
\hline Idea Bank S.A. & RKT-30/2014 & 4172571 & \\
\hline $\begin{array}{l}\text { Raiffeisen Bank } \\
\text { Polska S.A. }\end{array}$ & DDK-2/2014 & 21122088 & $\begin{array}{l}\text { stosowanie niedozwolonych praktyk na } \\
\text { etapach: przedkontraktowym, zawierania } \\
\text { umowy i jej wykonania; w szczególności: } \\
\text { brak uznawania odstąpienia od umowy } \\
\text { konsumentów w przewidzianym przez prawo } \\
\text { 30-dniowym terminie; nieinformowanie } \\
\text { klientów o tym, że oferowany Program } \\
\text { Pomnażania Oszczędności Kumulatus to } \\
\text { w rzeczywistości umowa ubezpieczenia na } \\
\text { życie z UFK; zatajenie, że wartość wykupu } \\
\text { w pierwszych latach umowy jest znacznie } \\
\text { niższa od wpłaconych składek }\end{array}$ \\
\hline TAX CARE S.A. & RGD.11/2015 & 770990 & $\begin{array}{l}\text { udzielanie konsumentom informacji } \\
\text { dotyczących produktów ubezpieczeniowych } \\
\text { z UFK, w sposób mogący wprowadzić } \\
\text { konsumentów w błąd co do cech tych } \\
\text { produktów dotyczących: rodzaju produktu, } \\
\text { okresu obowiązywania umowy, wysokości } \\
\text { i częstotliwości wnoszenia składki, } \\
\text { przewidywanych przyszłych zysków i korzyści, } \\
\text { ryzyka i opłat związanych z produktem }\end{array}$ \\
\hline
\end{tabular}

Źródło: opracowanie własne na podstawie informacji dostępnych na https://finanse.uokik.gov.pl/ufk/ decyzje-uokik (4.07.2017).

którzy zostali poszkodowani w wyniku nieuczciwych praktyk tych instytucji. Z jednej strony decyzje te pokazały, iż instytucje państwowe są chętne do pomocy konsumentom w wykrywaniu nieprawidłowości i ukaraniu tych, którzy nieuczciwe prak- 
tyki stosują. Z drugiej strony liczba postępowań oraz wydanych decyzji zapewne już wpłynęły na postrzeganie i zaufanie do sektora ubezpieczeniowego ${ }^{5}$.

O nieuczciwych praktykach ubezpieczycieli lub o podejrzeniu ich stosowania przez klientów dokonujących zakupu ubezpieczeń na życie z UFK świadczy także rosnąca liczba skarg i coraz większy udział tej grupy produktów w ogólnej liczbie skarg składanych do Rzecznika Ubezpieczonych. Informacje w tym zakresie dotyczące lat 2008-2015 zostały zaprezentowane w tabeli 2.

Tabela 2. Liczba skarg kierowanych do Rzecznika Ubezpieczonych w latach 2008-2015 dotyczących ubezpieczeń na życie z UFK

\begin{tabular}{|l|c|c|c|}
\hline Rok & $\begin{array}{c}\text { Skargi } \\
\text { dotyczące UFK }\end{array}$ & $\begin{array}{c}\text { Liczba skarg } \\
\text { ogółem }\end{array}$ & $\%$ \\
\hline 2008 & 51 & 7631 & 0,7 \\
\hline 2009 & 107 & 8566 & 1,3 \\
\hline 2010 & 103 & 11947 & 0,86 \\
\hline 2011 & 146 & 14356 & 1,01 \\
\hline 2012 & 516 & 15273 & 3,4 \\
\hline 2013 & 1216 & 16516 & 7,4 \\
\hline 2014 & 1422 & 15429 & 9,2 \\
\hline I-III kw 2015 & 1070 & 14273 & 7,5 \\
\hline
\end{tabular}

Źródło: opracowanie własne na podstawie raportów Rzecznika Ubezpieczonych ${ }^{6}$ oraz [Rzecznik Finansowy 2016].

Zaznaczyć należy, iż w 2016 r. napłynęła do Rzecznika Finansowego także liczna grupa wniosków dotyczących ubezpieczeń na życie z UFK. Wnioski te dotyczyły przede wszystkim sposobu naliczania, wymiaru i zwrotu składek ubezpieczeniowych, w tym najczęściej zwrotu całości składki bądź jej znacznej części w przypadku wcześniejszej rezygnacji z umowy, zbyt wygórowanej wysokości opłat likwidacyjnych, a także wprowadzania w błąd przy nabyciu produktu. Najważniejszym celem klientów wnoszących wnioski o polubowne rozwiązanie sporu było wycofanie się z danych produktów po wcześniejszym wynegocjowaniu warunków, które minimalizowałyby poniesione straty [Rzecznik Finansowy 2017].

Rola Rzecznika Ubezpieczonych (obecnie Rzecznika Finansowego) ${ }^{7}$, w kwestiach ochrony konsumentów korzystających z ubezpieczeń na życie z UFK, a tym samym poprawy jakości tych produktów, była i jest coraz większa. W latach 2013-

${ }^{5}$ Obszerny komentarz do decyzji wydanych przez Prezesa UOKiK dotyczących ubezpieczeń na życie z UFK można znaleźć w [Rzecznik Finansowy 2016].

${ }^{6}$ Dostępnych na: https://rf.gov.pl/publikacje/raporty-i-opracowania/Raporty_i_opracowania_ Rzecznika_Ubezpieczonych_lata_1995_2015_22166 (6.07.2017).

${ }^{7}$ Na podstawie ustawy o Rzeczniku Finansowym z dniem 11 października 2015 r. urząd Rzecznika Ubezpieczonych został przekształcony w urząd Rzecznika Finansowego, który przejął do dalszego prowadzenia sprawy skierowane do Rzecznika Ubezpieczonych [Ustawa z 5 sierpnia 2015]. 
2015 istotnie wzrosła liczba wniosków o przedstawienie oświadczeń zawierających istotny pogląd $\mathrm{w}$ sprawach dotyczących umów ubezpieczenia na życie z UFK, znacznie wzrósł także udział tych wniosków w ogólnej liczbie wszystkich wniosków kierowanych do Rzecznika (tab. 3). Ponadto w omawianych latach wzrosła także liczba przedstawionych istotnych dla sprawy poglądów przez Rzecznika Finansowego (tab. 4).

Tabela 3. Liczba wniosków o przedstawienie przez Rzecznika Finansowego oświadczenia zawierającego istotny dla sprawy pogląd

\begin{tabular}{|l|c|c|}
\hline Rok & $\begin{array}{c}\text { Liczba wniosków } \\
\text { o pogląd ogółem }\end{array}$ & $\begin{array}{c}\text { Liczba wniosków o pogląd dotycząca } \\
\text { ubezpieczeń na życie z UFK }\end{array}$ \\
\hline 2013 & 78 & 6 \\
\hline 2014 & 92 & 28 \\
\hline 2015 & 172 & 116 \\
\hline
\end{tabular}

Źródło: [Rzecznik Finansowy 2016].

Tabela 4. Tryb postępowania Rzecznika Finansowego w sprawie wniosków o przedstawienie oświadczenia zawierającego istotny dla sprawy pogląd dotyczący umowy ubezpieczenia na życie z UFK

\begin{tabular}{|l|c|c|c|}
\hline Rok & $\begin{array}{c}\text { Liczba przedstawionych } \\
\text { istotnych dla sprawy } \\
\text { poglądów }\end{array}$ & $\begin{array}{c}\text { Odmowa } \\
\text { przedstawienia } \\
\text { istotnego dla sprawy } \\
\text { poglądu }\end{array}$ & $\begin{array}{c}\text { Prośba o uzupełnienie } \\
\text { dokumentacji }\end{array}$ \\
\hline 2013 & 6 & 0 & 0 \\
\hline 2014 & 21 & 3 & 4 \\
\hline 2015 & 106 & 3 & 7 \\
\hline
\end{tabular}

Źródło: [Rzecznik Finansowy 2016].

Składane przez klientów skargi na niektóre zakłady ubezpieczeń na życie oferujące ubezpieczenia z grupy 3 działu I, jak również opublikowane przez Rzecznika Finansowego oraz UOKiK informacje i raporty dotyczące rozwoju produktów ubezpieczeń na życie z ubezpieczeniowym funduszem kapitałowym, stały się istotnym bodźcem do wprowadzenia nowych regulacji w tym zakresie. Świadomość klientów, że mogą bronić swojego bezpieczeństwa finansowego, jest tutaj nie tylko niezmiernie ważna, ale przede wszystkim wymusza nowe rozwiązania, w których jakość ochrony klientów będzie coraz lepsza.

Ponadto przedstawione powyżej dane powinny implikować nie tylko coraz większe wsparcie ze strony instytucji państwowych w kwestii poprawy jakości ubezpieczeń na życie z UFK, ale przede wszystkim pomoc w sytuacji wystąpienia nieuczciwych praktyk stosowanych przez instytucje finansowe, prowadzące do naruszenia interesów konsumentów. 
Piotr Pisarewicz, Patrycja Kowalczyk-Rólczyńska, Wojciech Kamieński

\section{Wybrane uregulowania formalnoprawne a ochrona klientów}

\subsection{Nadzór nad rynkiem finansowym a ochrona klientów zakładów ubezpieczeń}

Ustawa o nadzorze nad rynkiem finansowym określa w dużym zakresie organizację, zakres i cel sprawowania nadzoru nad rynkiem finansowym [Ustawa z 21 lipca 2006, art. 1.1]. W obszarze sektora ubezpieczeniowego sprawowany jest on zgodnie z przepisami Ustawy o działalności ubezpieczeniowej i reasekuracyjnej [Ustawa z 11 września 2015], a także Ustawy o pośrednictwie ubezpieczeniowym [Ustawa z 22 maja 2003], Ustawy r. o nadzorze ubezpieczeniowym i emerytalnym [Ustawa z 22 maja 2003] oraz Ustawy o ubezpieczeniach upraw rolnych i zwierząt gospodarskich [Ustawa z 7 lipca 2005]. Dodatkowym, przywołanym aktem prawnym w tym zakresie jest nadzór uzupełniający, sprawowany zgodnie z przepisami Ustawy o nadzorze uzupełniającym nad instytucjami kredytowymi, zakładami ubezpieczeń, zakładami reasekuracji i firmami inwestycyjnymi wchodzącymi w skład konglomeratu finansowego [Ustawa z 15 kwietnia 2005].

W treści Ustawy o nadzorze nad rynkiem finansowym nie wskazano wprost ani razu literalnego zwrotu „klient” lub „konsument”, więc bezpośrednie odniesienie do tego aspektu sprawy nie zostało w nim zawarte w tej formie. W tym kontekście użyto jedynie rozwiniętego nieco dalej określenia: „odbiorcy usług”, co, jak należy domniemywać, jest substytutem wymienionych zwrotów. Co do zasady jednak integralną częścią działalności organu nadzoru jest także dbałość o uczestników rynku - w tym ubezpieczonych, ubezpieczających oraz uprawnionych.

Elementy związane $\mathrm{z}$ badanym w niniejszym opracowaniu zagadnieniem można pośrednio odnaleźć we fragmentach Ustawy precyzujących zadania Komisji Nadzoru Finansowego. Wydaje się, iż zadania obejmujące podejmowanie działań służących prawidłowemu funkcjonowaniu rynku finansowego czy działań mających na celu rozwój rynku finansowego i jego konkurencyjności niejako z definicji wpisują się także w wątek ochrony klientów [Ustawa z 21 lipca 2006, art. 4.1]. Szczególnie istotny w tym zakresie jest natomiast zapis obligujący KNF do podejmowania działań edukacyjnych i informacyjnych w zakresie funkcjonowania rynku finansowego, jego zagrożeń oraz podmiotów na nim funkcjonujących w celu ochrony uzasadnionych interesów uczestników rynku finansowego. Objawia się to w szczególny sposób poprzez wpisywanie podmiotów na tzw. listę ostrzeżeń publicznych a także (co nie jest już raczej spotykane w praktyce) publikowanie - w formie i czasie przez siebie określonym - ostrzeżeń i komunikatów w publicznym radiu i telewizji w rozumieniu przepisów Ustawy o radiofonii i telewizji [Ustawa z 29 grudnia 1992; Ustawa z 21 lipca 2006, art. 4.1 ust. 4].

Do wątków związanych z ochroną klientów zaliczyć należy także obowiązek KNF stwarzania możliwości polubownego i pojednawczego rozstrzygania sporów między uczestnikami rynku finansowego, a w szczególności sporów wynikających ze stosunków umownych między podmiotami podlegającymi nadzorowi Komisji 
a odbiorcami usług świadczonych przez te podmioty [Ustawa z 21 lipca 2006, art. 4.1 ust. 6].

Jedną z aktywności, w której w szczególny sposób materializuje się wątek ochrony klientów, jest możliwość nakładania kar pieniężnych na zakłady ubezpieczeń, z czego KNF korzystał wielokrotnie. Przykładem może być nałożenie kar pieniężnych na Powszechny Zakład Ubezpieczeń S.A., Towarzystwo Ubezpieczeń i Reasekuracji „WARTA” S.A. i Link4 Towarzystwo Ubezpieczeń S.A., za naruszenie art. 14 ust. 1 i 3 ustawy o ubezpieczeniach obowiązkowych, Ubezpieczeniowym Funduszu Gwarancyjnym i Polskim Biurze Ubezpieczycieli Komunikacyjnych, w związku ze stwierdzeniem przypadków opóźnień w przyznaniu i wypłacie odszkodowania lub niedopełnienia obowiązków informacyjnych [KNF 2017a, b].

W kontekście problemu badawczego należy uwzględnić również nie mniej ważne akty tzw. miękkiego prawa (rekomendacje), uchwalane przez organ nadzoru kształtujące obowiązujące $\mathrm{w}$ praktyce standardy. W praktyce rynkowej ubezpieczyciele w bardzo dużym stopniu przestrzegają „nieobowiązkowych” zaleceń organu nadzoru, który na mocy nadanych mu uprawnień może w bardzo dotkliwy sposób ukarać podmiot niestosujący się do rekomendacji. Władze instytucji finansowych na ogół w pełni realizują oczekiwania rodzimego nadzorcy. W przypadkach zaniechania działań ubezpieczyciel musiałby wykazać i skutecznie przekonać organ nadzoru, iż jego zalecenia nie są zasadne i w przypadku danego podmiotu nie mogą być z jakiegoś względu wdrożone. W większości tego typu przypadków proces skończyłby się prawdopodobnie niepowodzeniem. Organ nadzoru realizuje kontrole w instytucjach ubezpieczeniowych, kończące się tzw. zaleceniami pokontrolnymi. $\mathrm{Na}$ ich mocy zakład ubezpieczeń byłby już zobligowany do realizacji wskazanych w rekomendacjach czynności. Nadto w praktyce rynkowej członkowie zarządów unikają konfliktów z organem nadzoru, który na mocy ustawy wyraża zgodę m.in. na objęcie funkcji prezesa lub członka zarządu ubezpieczyciela. Urzędujący członkowie zarządów nie ryzykują konfliktu z nadzorcą i ryzyka niewyrażenia zgody w przypadku zmiany miejsca pracy oraz chęci zasiadania $w$ zarządzie innej instytucji finansowej. Powyższy wywód ma na celu wskazanie, iż z różnych względów ubezpieczyciele przywiązują bardzo dużą wagę do tego typu ,aktów prawnych” (o tzw. miękkiej naturze) i w praktyce ich postanowienia są bardzo skrupulatnie realizowane. Poniżej wyszczególniono główne akty uchwalane przez organ nadzoru, które zawierają postanowienia w zakresie bezpieczeństwa i ochrony klientów. W ujęciu chronologicznym należy zaliczyć do wymienionych regulacji następujące dokumenty:

- Rekomendacje U dotyczaca dobrych praktyk w zakresie bancassurance, czerwiec 2014 r. [KNF 2014],

- Rekomendacje dla zaktadów ubezpieczeń dotyczace badania adekwatności produktu, 22 marca 2016 r. [KNF 2016a],

- Rekomendacje dla zakładów ubezpieczeń dotyczace systemu zarzadzania produktem, 22 marca 2016 r. [KNF 2016b], 
Piotr Pisarewicz, Patrycja Kowalczyk-Rólczyńska, Wojciech Kamieński

- Rekomendacje dotyczace procesu ustalania i wyplaty zadośćuczynienia z tytułu szkody niemajątkowej z umów ubezpieczenia OC posiadaczy pojazdów mechanicznych, czerwiec 2016 r. [KNF 2016c].

Ze względu na ograniczone ramy niniejszego opracowania dokładna analiza treści wymienionych rekomendacji nie jest zasadna, niemniej jednak należy stwierdzić, iż zawierają one zapisy bezpośrednio lub pośrednio mające na celu ochronę interesu klientów. Jako przykład mogą służyć ograniczenia dotyczące wypłaty wynagrodzeń dla banków z tytułu sprzedaży ubezpieczeń oraz inne ograniczenia wskazane w $R e$ komendacji $U$ skierowanej głównie do banków, choć w konsekwencji mającej bardzo duży wpływ na sytuację sektora ubezpieczeniowego. Niejako przy okazji wspomnieć należy także o tym, iż samo środowisko ubezpieczeniowe także wykazywało niejednokrotnie wolę poprawy wizerunku i rzeczywistej sytuacji w zakresie omawianej klasy produktów. Przykładem może być przyjęta 14 kwietnia 2014 r. przez Polską Izbę Ubezpieczeń Rekomendacja dobrych praktyk informacyjnych dotyczacych ubezpieczeń na życie zwiazanych z ubezpieczeniowymi funduszami kapitałowy$m i$, której uchwalenie miało bardzo istotne (nie tylko symboliczne) znacznie dla sektora i samych klientów [PIU 2014].

\subsection{Ochrona klientów a Ustawa z dnia 11 września 2015 r. o działalności ubezpieczeniowej i reasekuracyjnej}

Choć literalnie w treści Ustawy zwroty „klient” lub „konsument” nie widnieją, to rozumiane powinny być w dorozumieniu jako: ubezpieczający, ubezpieczony lub uprawniony (uposażony, beneficjent). Wydaje się, że to zestawienie ma głębokie uzasadnienie praktyczne, nawet pomimo tego, iż dwie ostatnie „strony” mają znacznie mniejsze obowiązki formalne niż sam ubezpieczający, który zawiera z zakładem ubezpieczeń umowę.

Bardzo istotnym dla odbiorców usług ubezpieczeniowych postanowieniem Ustawy jest obowiązek tworzenia i formułowania umów ubezpieczenia, ogólnych warunków ubezpieczenia oraz innych dokumentów w sposób jednoznaczny i zrozumiały dla klientów. W praktyce rynkowej ten element jest niezwykle trudny, ponieważ z natury rzeczy produkty ubezpieczeniowe oraz umowy są bardzo złożone.

Kolejnym postanowieniem będącym niejako pochodną postępu technologicznego jest obowiązek umieszczania przez ubezpieczycieli na swoich stronach internetowych ogólnych warunków ubezpieczenia oraz wzorców umów, co znacznie ułatwia zapoznanie się z nimi przez ubezpieczających.

W tym kontekście najbardziej istotny dla klientów wydaje się zapis ustawy wskazujący, iż postanowienia umów ubezpieczenia, ogólnych warunków ubezpieczenia oraz innych dokumentów sformułowane niejednoznacznie interpretuje się zawsze na korzyść ubezpieczającego, ubezpieczonego lub uprawnionego z umowy ubezpieczenia [Ustawa z 11 września 2015, art. 15.3-5]. Ustawodawca w sposób jednoznaczny uznał zatem odbiorców usług za stronę „słabszą" i wskazał orzekają- 
cym sądom, w jaki sposób co do zasady winny interpretować spory z zakładami ubezpieczeń. Mającymi ścisły związek z ochroną klientów są postanowienia art. 16 i 17 Ustawy, gdzie w 16 szczegółowych punktach wskazano minimalny zakres informacji, który powinien się znaleźć w każdych ogólnych warunkach ubezpieczenia i wzorcach umów dotyczących umów zarówno indywidualnych, jak i grupowych.

Ustawa zobligowała ministra właściwego do spraw instytucji finansowych do opracowania stosownego rozporządzenia w sprawie informacji zamieszczanych we wzorcach umów stosowanych przez zakład ubezpieczeń, które to rozporządzenie zostało w konsekwencji wydane 16 grudnia 2015 r. [Ustawa z 11 września 2015, art. 17 ust. 3; Rozporządzenie Ministra Finansów 2015].

W sposób szczególny jednak uregulowane zostały ubezpieczenia na życie, których szczegółowy zakres informacji, które należy przekazywać, doprecyzowano w odrębnym fragmencie Ustawy [Ustawa z 11 września 2015, art. 20]. Największą uwagę jednak zwrócono na ubezpieczenia grupy 3 działu I załącznika do Ustawy, które generowały w ostatnich dekadach najwięcej konfliktów, skarg i spraw sądowych. Zobligowano zakłady ubezpieczeń do pozyskiwania od ubezpieczających ankiet zawierających informacje o ich potrzebach, wiedzy i doświadczeniu w dziedzinie ubezpieczeń na życie oraz o ich sytuacji finansowej. Intencją takiego zapisu było dopasowanie odpowiedniej oferty do potrzeb ubezpieczającego. Do przygotowania stosownego wzorca takiej ankiety zobligowano ministra właściwego do spraw instytucji finansowych [Ustawa z 11 września 2015, art. 21]. Stosowne rozporządzenie w tym zakresie minister finansów wydał 10 lutego 2016 r. [Rozporządzenie Ministra Finansów 2016].

Aby zmniejszyć prawdopodobieństwo sporów, postanowiono, iż przed zawarciem umów ubezpieczenia na życie, jeżeli są związane z ubezpieczeniowymi funduszami kapitałowymi, zakłady ubezpieczeń powinny przekazywać potencjalnym klientom na piśmie lub na innym trwałym nośniku informacje dotyczące produktu, które pozwolą na jego prawidłową ocenę [Ustawa z 11 września 2015, art. 22].

Zakłady ubezpieczeń zostały zobowiązane także do publikowania wykazu ubezpieczeniowych funduszy kapitałowych wraz z ich regulaminami, zasad ustalania wartości świadczeń z tytułu śmierci i dożycia, całkowitego i częściowego wykupu ubezpieczenia, itp. [Ustawa z 11 września 2015, art. 23].

W związku z wprowadzeniem do Ustawy nowego brzmienia grupy 3 działu I postanowiono, iż w umowach ubezpieczenia na życie, w których wysokości świadczeń są ustalane w oparciu o określone indeksy lub inne wartości bazowe, zakłady ubezpieczeń powinny informować o kwestiach związanych $\mathrm{z}$ aktywami, w które lokowane są składki, sposobach ich wycen, zasadach ustalania wartości świadczeń itp. [Ustawa z 11 września 2015, art. 23].

Ścisły związek z ochroną klientów mają postanowienia Ustawy oraz przywołanej wcześniej Rekomendacji $U$ skierowanej do banków, gdzie wskazano m.in. ograniczenia w zakresie wypłat wynagrodzeń. Ustawodawca postanowił, iż w ubezpieczeniach na cudzy rachunek (w szczególności w ubezpieczeniach grupowych), 
ubezpieczający nie mogą otrzymywać wynagrodzeń lub innych korzyści wynikających z oferowania możliwości korzystania z ochrony ubezpieczeniowej lub czynności związanych z obsługą umów ubezpieczenia. Umożliwiono i doprecyzowano jednak w tym zakresie możliwość zobowiązania się przez ubezpieczonego wobec ubezpieczającego do finansowania kosztu składki ubezpieczeniowej.

Powyższym zakazem otrzymywania wynagrodzenia lub innych korzyści objęto również osoby działające na rzecz lub w imieniu ubezpieczającego. Swoistym odstępstwem od wymienionych reguł jest możliwość wypłaty wynagrodzeń z tytułu umów grupowych zawartych na rachunek pracowników lub osób wykonujących pracę na podstawie umów cywilnoprawnych oraz członków ich rodzin, a także umów zawartych na rachunek członków stowarzyszeń, samorządów zawodowych lub związków zawodowych [Ustawa z 11 września 2015, art. 19].

$\mathrm{W}$ umowach ubezpieczenia na życie, jeżeli są związane z ubezpieczeniowymi funduszami kapitałowymi, zawieranymi na okres nie dłuższy niż 5 lat, zakłady ubezpieczeń w zakresie wynagrodzeń pośredników ubezpieczeniowych kierować się powinny zasadą równomiernego rozłożenia w czasie wydatków z tytułu prowizji w okresie ubezpieczenia określonymi w umowach.

W umowach zawieranych na okres dłuższy niż 5 lat lub na czas nieokreślony zakłady ubezpieczeń powinny kierować się natomiast zasadą równomiernego rozłożenia w czasie wydatków z tytułu prowizji pośredników ubezpieczeniowych w okresie nie krótszym niż 5 lat.

Podobne rozwiązania zastosowano w umowach ubezpieczenia na życie, w których wysokości świadczeń są ustalane w oparciu o określone indeksy lub inne wartości bazowe [Ustawa z 11 września 2015, art. 24.3-4]. Z niektórych obowiązków z tym związanych wyłączono umowy ubezpieczenia, w których gwarantowana wysokość świadczeń z tytułu śmierci ubezpieczonego z dowolnej przyczyny jest wyższa niż dziesięciokrotność rocznych składek należnych z ich tytułu w każdym z pierwszych 5 lat ubezpieczenia [Ustawa z 11 września 2015, art. 23.5-7].

Istotnymi z punktu widzenia ochrony klientów postanowieniami są obowiązki informacyjne wobec ubezpieczających będących osobami fizycznymi o prawie właściwym dla umowy (gdy strony nie mają swobody wyboru prawa) lub prawie właściwym, którego wybór proponuje zakład ubezpieczeń (gdy strony mają swobodę wyboru prawa). Kolejną kwestią w tym zakresie są informacje dotyczące sposobu i trybu rozpatrywania skarg i zażaleń zgłaszanych przez ubezpieczających lub uprawnionych z umów ubezpieczenia, a także organu właściwego do ich rozpatrzenia [Ustawa z 11 września 2015, art. 25].

Praktyczny aspekt związany z zasadami i 60-dniowymi terminami odstąpień (po opublikowaniu sprawozdań) od zawartych przez ubezpieczających umów w dziale I w grupie 3 załącznika do Ustawy, także znalazł swoje miejsce w omawianym akcie prawnym. Kluczowym w tym kontekście zapisem jest jednak ograniczenie wysokości tzw. opłat likwidacyjnych do poziomu 4\% [Ustawa z 11 września 2015, art. 26]. Ten właśnie parametr legł w ostatnich latach u podstaw największej liczby skarg 
klientów oraz spraw i wyroków sądowych. Odrębną kategorią rozważań może być zakaz stosowania różnicowania składek ubezpieczeniowych i świadczeń poszczególnych osób wg kryterium płci [Ustawa z 11 września 2015, art. 34.1].

Nietypowe na tle powyższych rozważań może być podkreślenie roli niedocenianych na naszym rynku ubezpieczeń ochrony prawnej (dział II grupa 17 załącznika do Ustawy). Produkt sam w sobie zawiera szereg mechanizmów w szczególny sposób wspomagających klientów zakładów ubezpieczeń, które to mechanizmy co do zasady mają chronić ich szeroko pojęte interesy formalnoprawne. Dotyczy to wielu różnych usług, począwszy od prawa swobodnego wyboru adwokata lub radcy prawnego w zakresie obrony, reprezentowania lub wspierania interesów w postępowaniu sądowym lub administracyjnym. Zakres ubezpieczeń tego typu obejmuje również pokrycie kosztów postępowania sądowego oraz wykonania innych usług związanych bezpośrednio z ochroną ubezpieczeniową, a także zapewnienie odszkodowania $\mathrm{z}$ tytułu poniesionej przez ubezpieczonego straty, szkody lub uszkodzenia ciała przez ugodę pozasądową lub w postępowaniu cywilnym bądź karnym [Ustawa z 11 września 2015, art. 27].

Tego typu elementy konstrukcji produktów wpisują się znakomicie w szeroko pojmowany obszar ochrony klientów. Należy mieć nadzieję, iż produkty tego typu, podobnie jak w krajach Europy Zachodniej, będą zyskiwały popularność także w naszym kraju.

\section{Instytucjonalny wymiar ochrony klientów}

Poza przywołanymi we wstępie trzema podstawowymi przyczynami zawodności rynku usług finansowych należy wspomnieć o czwartej, wpływającej na poziom bezpieczeństwa obrotu oraz poziom ochrony klientów podmiotów rynku finansowego $^{8}$ - skuteczności instytucjonalnego wymiaru ochrony ich beneficjentów.

Efektywność instytucjonalnego wymiaru ochrony klienta usługi ubezpieczeniowej będzie przejawiać się w skuteczności działań podjętych przez organy administracji publicznej, których ustawowym celem jest ich ochrona. Cel ten jest wyrażony wprost w art. 2 ustawy o nadzorcze nad rynkiem finansowym [Ustawa z 21 lipca 2006], w art. 17 ustawy o rozpatrywaniu reklamacji przez podmioty rynku finansowego i o Rzeczniku Finansowym. Do realizacji tego celu nawiązuje także art. 1 i 2 ustawy o ochronie konkurencji i konsumentów [Ustawa z 16 lutego 2007].

Zgodnie ze wspomnianą wcześniej ustawą o nadzorze nad rynkiem finansowym celem nadzoru sprawowanego przez Komisję Nadzoru Finansowego jest ,zapewnienie prawidłowego funkcjonowania tego rynku, jego stabilności, bezpieczeństwa oraz przejrzystości, zaufania do rynku finansowego, a także zapewnienie ochrony interesów uczestników tego rynku również poprzez rzetelną informację dotyczącą

\footnotetext{
${ }^{8}$ Pojęcie „klienta podmiotu rynku finansowego” wprowadziła Ustawa o rozpatrywaniu reklamacji przez podmioty rynku finansowego i o Rzeczniku Finansowym [Ustawa z 5 sierpnia 2015].
} 
funkcjonowania rynku, przez realizację celów określonych”. Zgodnie z ustawą o Rzeczniku Finansowym „do zadań Rzecznika należy podejmowanie działań w zakresie ochrony klientów podmiotów rynku finansowego, których interesy reprezentuje”. Przedmiotem ustawy o ochronie konkurencji i konsumentów jest „określenie zasad podejmowanej w interesie publicznym ochrony interesów przedsiębiorców i konsumentów" oraz uregulowanie zasad i tryb przeciwdziałania praktykom naruszającym zbiorowe interesy konsumentów oraz stosowaniu niedozwolonych postanowień wzorców umów".

Wydawać by się mogło, że identyczność celów, a także ich spójność będzie stanowiła gwarancję, że prawa osób fizycznych zawierających z ubezpieczycielami umowę ubezpieczenia na życie z ubezpieczeniowym funduszem kapitałowym, prawa osób objętych ochroną ubezpieczeniową w ramach takich umów oraz osób uposażonych nie będą naruszane, a powołany wspomnianymi ustawami mechanizm nie tylko kontroli, ale przede wszystkim nadzoru, będzie skutecznie eliminować przejawy chociażby zagrożenia naruszenia takiego interesu.

Praktyka pokazała, że zagrożeniem dla instytucjonalnego wymiaru ochrony klientów ubezpieczycieli była taka realizacja celu nadzoru finansowego, która przeciwstawiała stabilność, bezpieczeństwo, przejrzystość i zaufanie do rynku finansowego ochronie interesów jego uczestników, stwarzając niebezpieczeństwo realizacji pierwszego kosztem drugiego. Mogło to paradoksalnie prowadzić do takiego pojmowania celu nadzoru nad rynkiem finansowym, który przedkładał stabilność finansową ubezpieczycieli oferujących ubezpieczenia z UFK nad zapewnienie należytej ochrony interesów osób inwestujących środki pieniężne w ubezpieczenia typu unit-linked. Nie wydaje się, aby działalność Rzecznika Finansowego (wcześniej Rzecznika Ubezpieczonych) i Urzędu Ochrony Konkurencji i Konsumentów wskazywała na niebezpieczeństwo rozumienia swoich zadań w kontekście antynomii interesu klientów (konsumentów) - bezpieczeństwo rynku finansowego postrzeganego przez pryzmat przedsiębiorców oferujących usługi finansowe, czy ubezpieczeniowe w szczególności.

Dla oceny efektywności działań systemowych podjętych przez przywołane instytucje nie bez znaczenia były dwa raporty Rzecznika Finansowego poświęcone umowie ubezpieczenia na życie $\mathrm{z}$ ubezpieczeniowym funduszem kapitałowym [Rzecznik Ubezpieczonych 2012; Rzecznik Finansowy 2016]. Raporty Rzecznika, a zwłaszcza pierwszy raport z 2012 r., stanowiły odpowiedź na rosnącą falę skarg klientów zakładów ubezpieczeń na ubezpieczenia na życie z UFK i były podsumowaniem działań systemowych podjętych nie tylko przez Rzecznika, ale także przez pozostałe instytucje publiczne. Pierwszy raport stanowił rozbudowaną analizę kontraktu cywilnego jakim jest umowa ubezpieczenia na życie z ubezpieczeniowym funduszem kapitałowym, a także jego specyficznej odmiany, jaką jest umowa grupowego ubezpieczenia na życie i dożycie z ubezpieczeniowym funduszem kapitałowym powiązanym $\mathrm{z}$ indeksem. W przekonaniu Rzecznika w oferowanych przez rynek umowach zastrzeżone były opłaty likwidacyjne, które nosiły znamiona niedo- 
zwolonych postanowień umów, same umowy dawały niską efektywność ubezpieczenia jako finansowego produktu oszczędnościowo-inwestycyjnego. Rzecznik formułował także wątpliwości co do ważności umowy ubezpieczenia w przypadku iluzorycznej ochrony ubezpieczeniowej bądź wykonywania przez ubezpieczycieli działalności typu asset management, która przypomina w swojej specyfice działalność inwestycyjną bądź maklerską. Drugi raport Rzecznika Finansowego poświęcony ubezpieczeniom z UFK stanowił podsumowanie stanu rynku ubezpieczeniowego po czterech latach jego funkcjonowania od czasu pierwszego raportu. Zauważalne było podjęcie inicjatyw zarówno przez UOKiK, jak i przez KNF, który wydał rekomendacje dotyczące adekwatności produktu i zarządzania produktem oraz dotyczące dystrybucji ubezpieczeń. Wskazał także na próby regulacji rynku pod auspicjami Polskiej Izby Ubezpieczeń oraz Związku Banków Polskich.

Warto dodać, że wśród działań systemowych podejmowanych przez Rzecznika Finansowego jest formułowanie istotnych poglądów w sprawach cywilnych ${ }^{9}$. W kontekście ubezpieczeń na życie z ubezpieczeniowym funduszem kapitałowym dotyczyły one przede wszystkim oceny opłat likwidacyjnych lub terminologicznie do nich zbliżonych o identycznym znaczeniu funkcjonalnym (opłaty za zarządzanie, opłaty warunkowe), wartości wykupu jako ukrytej opłaty likwidacyjnej oraz nieważności umowy ubezpieczenia $z$ ubezpieczeniowym funduszem kapitałowym powiązanym z indeksem ze względu na sprzeczność z właściwością stosunku prawnego oraz nieobjęcie konsensem minimalnej treści czynności prawnej. Rozbudowany pogląd istotny dla sprawy Rzecznik Finansowy zajął w związku z zapytaniem Sądu Okręgowego w Warszawie skierowanym do Sądu Najwyższego, dotyczącym tego, czy wartość wykupu stanowi świadczenie w umowie ubezpieczenia na życie z ubezpieczeniowym funduszem kapitałowym ${ }^{10}$.

Analizując efektywność działań podejmowanych dla efektywności instytucjonalnego wymiaru ochrony klienta usługi ubezpieczeniowej nie sposób nie zauważyć działań prezesa UOKiK, a zwłaszcza wszczęcia postępowań i wydania decyzji zobowiązującej ubezpieczycieli oferujących ubezpieczenia na życie z ubezpieczeniowym funduszem kapitałowym, po uprawdopodobnieniu stosowania praktyk naruszających zbiorowe interesy konsumentów ${ }^{11}$, do zmiany sposobu lub wysokości opłaty

9 Podstawę formułowania poglądu istotnego w sprawie jest art. 28 Ustawy o rozpatrywaniu reklamacji przez podmioty rynku finansowego i o Rzeczniku Finansowym [Ustawa z 5 sierpnia 2015].

${ }^{10}$ Sąd Okręgowy w Warszawie podczas rozpoznawania apelacji w sprawie o sygn. V Ca 568/15 doszedł do przekonania, że powstało zagadnienie prawne budzące poważne wątpliwości i w trybie art. 390 k.p.c. przedstawił Sądowi Najwyższemu do rozstrzygnięcia pytanie prawne o następującej treści: „czy świadczenie wypłacane przez ubezpieczyciela w przypadku przedterminowego rozwiązania umowy ubezpieczenia na życie wraz z ubezpieczeniowym funduszem kapitałowym jest świadczeniem głównym, czy ubocznym".

${ }^{11}$ Zgodnie z art. 24 ust. 2 pkt 3 Ustawy o ochronie konkurencji i konsumentów [Ustawa z 16 lutego 2007] przez praktykę naruszającą zbiorowe interesy konsumentów rozumie się godzące w nie bezprawne działanie przedsiębiorcy, w szczególności stosowanie nieuczciwych praktyk rynkowych. Zgodnie z art. 3 ust. 1 Ustawy o zwalczaniu nieuczciwej konkurencji [Ustawa z 16 kwietnia 1993] zakazane 
likwidacyjnej bądź do niej zbliżonej (zob. np. [Prezes UOKiK 2015]). Przesłankami uznania, że pobieranie opłat likwidacyjnych stanowi praktykę naruszającą zbiorowe interesy konsumentów była konstatacja, że pozbawienie konsumenta (ubezpieczonego) całości albo znacznej części środków zgromadzonych na rachunku jednostek uczestnictwa jest sprzeczne z dobrymi obyczajami, których przejawem jest zapewnienie równości kontraktowej i równomiernego ponoszenia ryzyka przez każdą ze stron umowy cywilnoprawnej. W przekonaniu prezesa UOKiK przerzucenie na konsumenta (ubezpieczonego) kosztów akwizycyjnych, na które składają się w przeważającej mierze koszty prowizji agenta ubezpieczeniowego, jest nieuzasadnionym przeniesieniem przez przedsiębiorcę ryzyka gospodarczego w sytuacji, kiedy konsument rezygnuje $z$ kontynuacji ubezpieczenia. W decyzjach uprawdopodabniających naruszenie zbiorowych interesów konsumentów podniesiona została także sprzeczność z prawem polegająca na faktycznym pozbawieniu ubezpieczającego prawa do wypowiedzenia umowy ubezpieczenia na życie w każdym czasie (art. 830 k.c.), jeżeli wiąże się z tym utrata całości albo znacznej części wpłaconych środków.

Warto dodać, że w przeciwieństwie do działań Rzecznika Finansowego oraz Prezesa Urzędu Ochrony Konkurencji i Konsumentów, działania Komisji Nadzoru Finansowego były związane głównie z wydawaniem rekomendacji nie mających charakteru takich działań prawnych, których nierespektowanie wiązałoby się z podjęciem konkretnych sankcji prawnych. Wobec ubezpieczycieli stosujących opłaty likwidacyjne KNF nie nałożył kary finansowej ani nie wydał zalecenia w tym przedmiocie. Zgodnie z art. 209 ust. 1 Ustawy z dnia 22 maja 2003 r. o działalności ubezpieczeniowej ${ }^{12}$ organ nadzoru mógł wydawać zalecenia w stosunku do zakładu ubezpieczeń $\mathrm{w}$ celu zapewnienia zgodności działalności zakładu ubezpieczeń z przepisami prawa (pkt 1) oraz zapobieżenia naruszaniu interesów ubezpieczających, ubezpieczonych, uposażonych lub uprawnionych z umów ubezpieczenia (pkt 3).

Wobec zarzutów stawianych Komisji Nadzoru Finansowego, 20 maja 2014 r. przewodniczący KNF wystosował pismo do Marszałka Senatu $\mathrm{RP}^{13}$, w którym dokonał oceny działania Komisji, jak i swojego Urzędu, które musiało uwzględniać między innymi cywilnoprawny wymiar spraw, co do których KNF nie posiadał kompetencji do rozstrzygania sporów pomiędzy klientami a podmiotami nadzorowanymi.

Warto także dodać, że w Ministerstwie Sprawiedliwości został powołany zespół roboczy, który ma się zająć nadużyciami związanymi ze sprzedażą polis z ubezpie-

jest działanie sprzeczne z prawem lub dobrymi obyczajami, jeżeli zagraża lub narusza interes innego przedsiębiorcy lub klienta. W art. 3 ust. 2 tej Ustawy ustawodawca dokonał przykładowego wyliczenia czynów będących czynami nieuczciwej konkurencji.

${ }_{12}$ Obecnie aktem prawnym regulującym prowadzenie działalności ubezpieczeniowej i sprawowanie nadzoru przez Komisję Nadzoru Finansowego jest Ustawa o działalności ubezpieczeniowej i reasekuracyjnej [Ustawa z 11 września 2015].

13 Wystąpienie z dnia 20 maja 2014 r. Przewodniczącego KNF Andrzeja Jakubiaka do Marszałka Senatu RP Bogdana Borusewicza [http://www.senat.gov.pl/gfx/senat/userfiles/_public/k8/dokumenty/ stenogram/oswiadczenia/bierecki/5202o.pdf]. 
czeniowym funduszem kapitałowym. Celem grupy roboczej jest przygotowanie zmian legislacyjnych w zakresie działalności ubezpieczeniowej i dochodzenia roszczeń $\mathrm{w}$ postępowaniu grupowym ${ }^{14}$.

\section{Zakończenie}

Przywołany na początku opracowania rozwój rynków oraz produktów finansowych w zestawieniu ze wzrostem zamożności społeczeństwa spowodował, iż w ostatnich dwóch dekadach w naszym kraju klienci coraz aktywniej zaczęli angażować swoje środki we wszelkiego rodzaju usługi finansowe. Jednym z przykładów są ubezpieczenia na życie, gdy ryzyko lokaty (inwestycyjne) ponosi ubezpieczający, a w szczególności ubezpieczenia na życie z ubezpieczeniowym funduszem kapitałowym. Ta klasa produktów spowodowała bodaj najwięcej kontrowersji i sporów na tle ich konstrukcji, strony formalnoprawnej, sposobu dystrybucji oraz wynagradzania pośredników. Potwierdziły to przywołane w pierwszej części opracowania statystyki rynkowe wskazujące na rosnącą liczbę skarg ze strony klientów oraz decyzji i kar UOKiK. Na tym tle poddano analizie kluczowe zagadnienia dotyczące formalnoprawnego i instytucjonalnego wymiaru systemu ochrony klientów w zakresie produktów obejmujących grupę 3 działu I załącznika do Ustawy o działalności ubezpieczeniowej i reasekuracyjnej. W wymiarze prawa poddano badaniu zapisy regulacji dotyczących nadzoru nad rynkiem finansowym, gdzie kluczową rolę odgrywa Komisja Nadzoru Finansowego. Wydaje się, iż od strony formalnoprawnej interes klientów jest w tym zakresie chroniony w sposób niebudzący większych zastrzeżeń, niemniej jednak od strony faktycznej organ nadzoru mógł w przeszłości podjąć w wielu przypadkach kroki mające na celu lepszą i skuteczniejszą ich ochronę (wątki z tym związane poruszone zostały w końcowej części opracowania). Autorzy Ustawy o działalności ubezpieczeniowej i reasekuracyjnej bardzo dużo uwagi poświęcili szeroko pojętej ochronie klientów, co znalazło swój wyraz we wskazanych w części drugiej zapisach mających na celu zmniejszenie prawdopodobieństwa nadużyć a także asymetrii między klientem a ubezpieczycielem. Na podkreślenie zasługują także działania UOKiK oraz Rzecznika Finansowego, którzy niejako z definicji chronią szerokie rzesze klientów instytucji finansowych.

Podsumowując, należy stwierdzić, iż na podstawie przeprowadzonych badań formalnoprawny oraz instytucjonalny wymiar ochrony klientów w naszym kraju uznać należy co do zasady za prawidłowy i niebudzący większych zastrzeżeń. Przyczyniły się do tego m.in. chroniące klientów zapisy Ustawy o działalności ubezpieczeniowej i reasekuracyjnej, a także działania organów państwowych. Nie oznacza to jednak pozytywnej oceny w każdym obszarze ich funkcjonowania, ponieważ

${ }^{14}$ Pierwsze spotkanie zespołu roboczego odbyło się 27 marca 2017 r. Zob. także: [https://ms.gov. pl/pl/informacje/news, 9190,zespol-do-walki-z-patologia-polisolokat.html]. 
w przeszłości mogły podejmować bardziej zdecydowane działania chroniące klientów instytucji finansowych w większym zakresie. Postępujący rozwój usług finansowych oraz rosnąca konkurencja powinny wymuszać w najbliższej przyszłości równoległy postęp w zakresie zapisów aktów prawnych, a w szczególności w sferze operacyjnej, gdzie powołane do tego instytucje powinny jeszcze skuteczniej niż obecnie chronić długoterminowy interes klientów zakładów ubezpieczeń oraz pozostałych instytucji działających na rynku finansowym.

\section{Literatura}

Borkowski A., 2012, Wybrane zagadnienia związane z ochrona konsumentów na rynku pośrednictwa Ubezpieczeniowego, Wiadomości Ubezpieczeniowe, nr 2, s. 45-64.

Grzebieniak A., 2008, Świadomość ubezpieczeniowa konsumenta jako warunek lojalności wobec zakładu ubezpieczeń, Studia Gdańskie, t. V, s. 276-284.

Iwko J., Iwko J., 2015, Świadomość ubezpieczeniowa indywidualnych klientów zakładów ubezpieczeń z terenu województwa dolnośląskiego na tle badań ankietowych, Rozprawy Ubezpieczeniowe, nr 19 (2/2015), s. 89-114.

KNF, 2014, Rekomendacja U dotyczaca dobrych praktyk w zakresie bancassurance, Komisja Nadzoru Finansowego, Warszawa, czerwiec 2014 r.

KNF, 2016a, Rekomendacje dla zakładów ubezpieczeń dotyczące badania adekwatności produktu, Komisja Nadzoru Finansowego, Warszawa.

KNF, 2016b, Rekomendacje dla zakładów ubezpieczeń dotyczace systemu zarządzania produktem, Komisja Nadzoru Finansowego, Warszawa.

KNF, 2016c, Rekomendacje dotyczące procesu ustalania i wypłaty zadośćuczynienia z tytułu szkody niemajątkowej z umów ubezpieczenia OC posiadaczy pojazdów mechanicznych, Komisja Nadzoru Finansowego, Warszawa.

KNF, 2017a, Komunikat z 356. posiedzenia Komisji Nadzoru Finansowego z dnia 26 maja 2017 r., Komisja Nadzoru Finansowego, Warszawa.

KNF, 2017b, Komunikat z 362. posiedzenia Komisji Nadzoru Finansowego z dnia 27 czerwca 2017 r., Komisja Nadzoru Finansowego, Warszawa.

Marcinkowska M., 2011, Ochrona klientów banków poprzez informację, Acta Universitatis Lodziensis. Folia Oeconomica, nr 247, s. 5-19.

Mrozowska-Bartkiewicz B., 2013, Karta Produktu - kluczowe informacje dla konsumentów dotyczace ubezpieczeniowych produktów na życie z UFK, Prawo Asekuracyjne, nr 4/2013 (77), s. 59-77.

NIK, 2011, Informacja o wynikach kontroli ochrony interesów klientów zakładów ubezpieczeń oraz członków funduszy emerytalnych, Najwyższa Izba Kontroli, Warszawa.

NIK, 2014, Funkcjonowanie systemu ochrony praw klientów podmiotów rynku finansowego, Najwyższa Izba Kontroli, Warszawa.

PIU, 2014, Rekomendacja dobrych praktyk informacyjnych dotyczacych ubezpieczeń na życie związanych z ubezpieczeniowymi funduszami kapitałowymi, Polska Izba Ubezpieczeń, Warszawa.

Prezes UOKiK, 2015, Decyzja nr RBG-14/2015 Prezesa UOKiK z dnia 28 grudnia 2015 r. dotycząca AEGON Towarzystwo Ubezpieczeń na Życie S.A. z siedzibą w Warszawie, https://uokik.gov.pl.

Przybytniowski J.W., 2014, Rozwój rynku kanałów świadczenia usług ubezpieczeniowych. Polska na tle krajów Unii Europejskiej. Finanse: Czasopismo Komitetu Nauk o Finansach PAN, nr 1 (7), s. 171-197. 
Rzecznik Finansowy, 2016, Ubezpieczenia na życie z ubezpieczeniowym funduszem kapitałowym. Raport Rzecznika Finansowego, https://rf.gov.pl/publikacje/raporty-i-opracowania/II_Raport_ Rzecznika_Finansowego__Ubezpieczenia_na_zycie_z_ubezpieczeniowym_funduszem_kapitalowym_data_publikacji_31_22288

Rzecznik Finansowy, 2017, Sprawozdanie Rzecznika Finansowego i jego biura z działalności w 2016 r., Warszawa.

Rzecznik Ubezpieczonych, 2012, Raport Rzecznik Ubezpieczonych - Ubezpieczenia na życie z ubezpieczeniowym funduszem kapitałowym, https://rf.gov.pl/publikacje/raporty-i-opracowania/Raport_Rzecznika_Ubezpieczonych_Ubezpieczenia_na_zycie_z_ubezpieczeniowym_funduszem_kapitalowym_21129 (11.05.2017).

Sury P., 2014, Praktyka bancassurance a przepisy karne ustawy o pośrednictwie ubezpieczeniowym, Prokuratura i Prawo, nr 10, s. 103-122.

Szumlicz T., 2006, Atrybuty świadomości i przezorności ubezpieczeniowej, Rozprawy Ubezpieczeniowe, nr $1(1 / 2006)$, s. 21-26.

Walczak D., Żołądkiewicz A., 2011, Świadomość ubezpieczeniowa oraz skłonność do ryzyka studentów, [w:] Ronka-Chmielowiec W. (red.), Ubezpieczenia wobec wyzwań XXI wieku, Prace Naukowe Uniwersytetu Ekonomicznego we Wrocławiu, nr 228, s. 515-524.

Wieteska S., 2010, Świadomość czy samoświadomość ubezpieczeniowa, Annales. Etyka w życiu gospodarczym, vol. 13, nr 1, s. 231-238.

Wrzesiński P., 2015, Uchylenie się od skutków prawnych umowy ubezpieczenia na życie z ubezpieczeniowym funduszem kapitatowym na podstawie błędu lub podstępu, Prawo Asekuracyjne, nr 2/2015 (83), s. 39-55.

\section{Akty prawne}

Rozporządzenie Ministra Finansów z dnia 16 grudnia 2015 r. w sprawie informacji zamieszczanych we wzorcach umów stosowanych przez zakład ubezpieczeń, Warszawa.

Rozporządzenie Ministra Finansów z dnia 2 lutego 2016 r. w sprawie minimalnego zakresu danych zamieszczanych $\mathrm{w}$ ankiecie dotyczącej potrzeb ubezpieczającego lub ubezpieczonego, Warszawa.

Ustawa z dnia 29 grudnia 1992 r. o radiofonii i telewizji, Dz.U. 2015 poz. 1531 i 1830 oraz 2016 poz. 25.

Ustawa z dnia 16 kwietnia 1993 r. o zwalczaniu nieuczciwej konkurencji, tekst jedn. Dz.U. 2003 Nr 253, poz. $1503 \mathrm{ze} \mathrm{zm}$.

Ustawa z dnia 22 maja 2003 r. o działalności ubezpieczeniowej, tekst jedn. Dz.U. 2015 r. poz. 1206, ze zm.

Ustawa z dnia 22 maja 2003 r. o nadzorze ubezpieczeniowym i emerytalnym, Dz.U. 2016 r. poz. 477.

Ustawa z dnia 22 maja 2003 r. o pośrednictwie ubezpieczeniowym, Dz.U. 2014 poz. 1450 oraz 2015 poz. 1844 i 1893.

Ustawa z dnia 15 kwietnia 2005 r. o nadzorze uzupełniającym nad instytucjami kredytowymi, zakładami ubezpieczeń, zakładami reasekuracji i firmami inwestycyjnymi wchodzącymi w skład konglomeratu finansowego, Dz.U. 2014 poz. 1406 oraz 2015 poz. 1844.

Ustawa z dnia 7 lipca 2005 r. o ubezpieczeniach upraw rolnych i zwierząt gospodarskich, Dz.U. 2015 r. poz. 577,892 i 1844 .

Ustawa z dnia 21 lipca 2006 r. o nadzorze nad rynkiem finansowym, Dz.U. 2016 poz. 174, 615, 888, $996,1823$.

Ustawa z dnia 16 lutego 2007 r. o ochronie konkurencji i konsumentów, tekst jedn. Dz.U. 2015 poz. 184. 
Ustawa z dnia 5 sierpnia 2015 r. o rozpatrywaniu reklamacji przez podmioty rynku finansowego i o Rzeczniku Finansowym, Dz.U. 2016 r. poz. 892 ze zm.

Ustawa z dnia 11 września 2015 r. o działalności ubezpieczeniowej i reasekuracyjnej, Dz.U. 2015 poz. 1844.

\section{Źródla internetowe}

https://finanse.uokik.gov.pl/ufk/decyzje-uokik (4.07.2017).

https://ms.gov.pl/pl/informacje/news,9190,zespol-do-walki-z-patologia-polisolokat.html.

https://rf.gov.pl/publikacje/raporty-i-opracowania/Raporty_i_opracowania_Rzecznika_Ubezpieczonych_lata_1995_2015_22166 (6.07.2017).

http://www.senat.gov.pl/gfx/senat/userfiles/_public/k8/dokumenty/stenogram/oswiadczenia/bierecki /52020.pdf (6.07.2017). 